\title{
Diurnal Variation in Glucose Tolerance: Associated Changes in Plasma Insulin, Growth Hormone, and Non-esterified Fatty Acids
}

\author{
P. Z. ZIMMET, J. R. WALL, R. ROME, L. STIMMLER, R. J. JARRETT
}

British Medical fournal, 1974, 1, 485-491

\begin{abstract}
Summary
Oral glucose tolerance tests were performed in the morning and afternoon of separate days on 31 people derived from a normal population sample. Blood sugar levels were higher in the afternoon test from and including 60 minutes after the glucose load. The degree of diurnal variation was similar in men and women, but greater in the older half of the group. It was negatively correlated with the degree of obesity. The plasma insulin response was less at the 30 minute time point in the afternoon, but significantly exceeded the morning values at 120 and 150 minutes after the glucose load. Growth hormone levels were similar in morning and afternoon tests. Fasting non-esterified fatty acid levels were significantly higher before the afternoon test.

The relatively impaired glucose tolerance in the afternoon is associated with a delayed insulin response to the glucose load. This seems unlikely to be the sole explanation, however, and increased non-esterified fatty acid metabolism with a consequent decrease in glucose disposal may also contribute.
\end{abstract}

\section{Introduction}

The phenomenon of diurnal variation in oral glucose tolerance, with a worsening in the afternoon and evening compared with morning responses, is well documented (Roberts, 1964; Bowen and Reeves, 1968; Jarrett and Keen, 1969 and 1970; Jarrett et al., 1972; Carroll and Nestel, 1973; Oakley et al., 1973). Previous studies, however, have been of selected groups of subjects and in most the observations were confined to measurements of blood sugar. The present investigation was designed to study a wide sample of both men and women and to measure several other substances which might play a part in glucose tolerance.

\section{Subjects and Methods}

The subjects were employees of the Greater London Council and the Inner London Education Authority who had previously participated in an epidemiological survey of a stratified but otherwise random sample comprising 1,005 persons. Each participant was asked to volunteer for further studies and from the volunteers a sample was asked to participate in the present investigation. A sampling frame was used to ensure adequate

Guy's Hospital, London S.E.1

P. Z. ZIMMET, PH.D., M.R.A.C.P., Research Associate

J. R. WALL, M.D., M.R.A.C.P., Research Associate

J. R. WALL, M.D., M.R.A.C.P., Resear

L. STIMMLER, M.D., M.R.C.P., Senior Lecturer, Department of Paediatrics

R. J. JARRETT, M.D., M.F.C.M., Senior Lecturer, Departments of Medicine and Community Medicine representation across the age range. The only reasons for exclusion were acute or subacute illness or pregnancy. The age and sex distribution of the group is shown in table $\mathrm{I}$.

TABLE I-Age and Sex Distribution of Subjects Studied

\begin{tabular}{|c|c|c|c|c|c|c|}
\hline & Age Range & $20-29$ & $30-39$ & $40-49$ & $50-59$ & $60-69$ \\
\hline $\begin{array}{l}\text { Men.. } \\
\text { Women }\end{array}$ & $\ldots$ & $\begin{array}{l}3 \\
2\end{array}$ & $\begin{array}{l}3 \\
3\end{array}$ & $\begin{array}{l}4 \\
3\end{array}$ & $\begin{array}{l}2 \\
6\end{array}$ & $\begin{array}{l}3 \\
2\end{array}$ \\
\hline
\end{tabular}

All subjects had had a normal diet with adequate amounts of carbohydrate before the tests. The period of fasting was nine to 10 hours before the morning test and seven to eight hours before the afternoon test. The last meal before the fast consisted of about $50 \mathrm{~g}$ of carbohydrate as a jam or marmalade sandwich. The morning and afternoon tests were performed in random order, usually with an interval of seven days between them. Subjects reported for the morning test between 08.45 and 09.00 and for the afternoon test between 14.00 and 14.15. The duration of "ambulation" and the amount and kind of exercise before the tests were not controlled.

Oral glucose tolerance tests were performed using a standard load of $50 \mathrm{~g}$ liquid glucose ( $235 \mathrm{ml}$ of Lucozade). Venous blood samples were obtained via an indwelling venous catheter at $0,30,90,120$, and 150 minutes. Subjects were recumbent during the test and rested for 30 minutes after insertion of the catheter before the first sample was taken. Blood samples were centrifuged immediately and the plasma separated, frozen, and stored at $-15^{\circ} \mathrm{C}$ until assayed. Blood sugar (whole blood) was estimated by the ferricyanide reduction micromethod on an AutoAnalyzer (Technicon method N-9a). Plasma insulin and growth hormone were determined by a double-antibody method and non-esterified fatty acids by the method of Carruthers and Young (1973). Statistical comparisons were made using the paired or unpaired $t$ test where appropriate.

\section{Results}

BLOOD SUGAR

The mean blood sugar levels in the afternoon were significantly higher in the whole group at all time points except fasting and at 30 minutes after the glucose load. In our previous investigations the blood sugar was monitored only until 120 minutes. As this study shows, blood sugar levels were still significantly higher in the afternoon test at 150 minutes and had not returned to baseline.

Effect of Age.-Our previous studies were of older age groups. The subjects in the present study were divided into those aged less than 45 years, the modal age $(n=15)$, and those over 45 $(n=16)$. There was no significant difference between the morning blood sugar levels in the two groups and the difference between the morning and afternoon levels showed the same pattern as described for the whole group (table III, fig. 2). Nevertheless, the afternoon values at 90,120 , and 150 minutes were significantly higher in the older age group-that is, the 
TABLE II-Mean ( \pm S.E.M.) Blood Sugar Levels $(\mathrm{mg} / 100 \mathrm{ml})$ Morning and Afternoon in Whole Group

\begin{tabular}{|c|c|c|c|c|c|c|c|c|c|c|}
\hline & & & & & \multicolumn{6}{|c|}{ Time (minutes) } \\
\hline & & & & & 0 & 30 & 60 & 90 & 120 & 150 \\
\hline $\begin{array}{l}\text { Morning } \\
\text { Afternoon }\end{array}$ & $\begin{array}{ll} & \\
\cdots & \cdots\end{array}$ & $\begin{array}{l}. \\
\cdots\end{array}$ & $\begin{array}{l}\cdots \\
\cdots\end{array}$ & $\begin{array}{l}\cdots \\
\cdots\end{array}$ & $\begin{array}{l}80 \cdot 3 \pm 1 \cdot 7 \\
76 \cdot 0 \pm 1 \cdot 4\end{array}$ & $\begin{array}{l}119 \cdot 1+3 \cdot 5 \\
110 \cdot 8 \pm 3 \cdot 3\end{array}$ & $\begin{array}{l}125 \cdot 9 \pm 4 \cdot 9 \\
146 \cdot 6 \pm 5 \cdot 2\end{array}$ & $\begin{array}{r}98 \cdot 7+3 \cdot 3 \\
146 \cdot 0+4 \cdot 9\end{array}$ & $\begin{array}{r}82 \cdot 0 \pm 2 \cdot 7 \\
123 \cdot 5 \pm 4 \cdot 8\end{array}$ & $\begin{array}{r}74 \cdot 0 \pm 2 \cdot 7 \\
102 \cdot 8 \pm 4 \cdot 5\end{array}$ \\
\hline
\end{tabular}

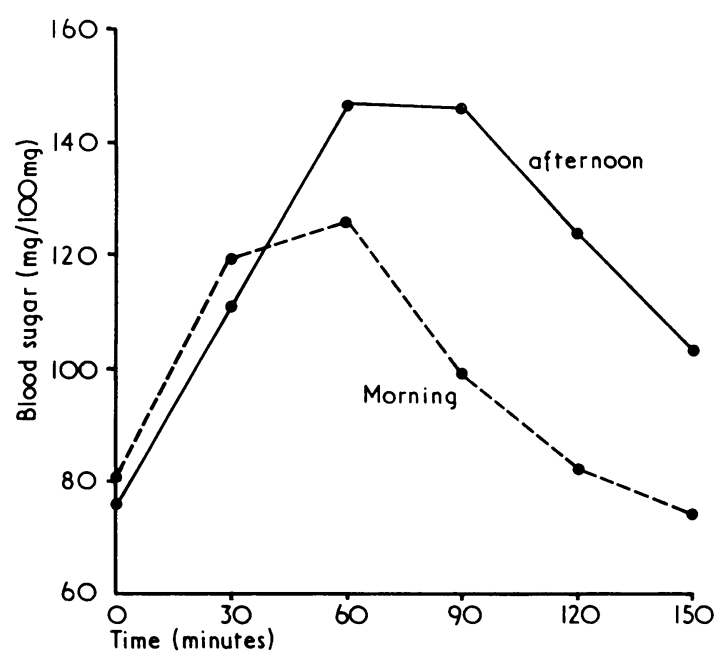

FIG. 1-Mean blood sugar levels $(\mathrm{mg} / 100 \mathrm{ml})$ for whole group in the two glucose tolerance tests.

TABLE III-Mean ( \pm S.E.M.) Blood Sugar Levels Morning and Afternoon by Age Group

\begin{tabular}{c|r|r|r|r}
\hline \multirow{2}{*}{$\begin{array}{c}\text { Time } \\
\text { (minutes) }\end{array}$} & \multicolumn{2}{|c|}{$22-44$ Years $(\mathrm{n}=15)$} & \multicolumn{2}{|c}{$45-65$ Years $(\mathrm{n}=16)$} \\
\cline { 2 - 5 } & \multicolumn{1}{|c|}{ Morning } & Afternoon & Morning & Afternoon \\
\hline 0 & $83 \cdot 1 \pm 2 \cdot 5$ & $77 \cdot 1+1 \cdot 7$ & $77 \cdot 6 \pm 2 \cdot 3$ & $75 \cdot 0+2 \cdot 2$ \\
30 & $122 \cdot 0 \pm 4 \cdot 2$ & $112 \cdot 5 \pm 5 \cdot 1$ & $116 \cdot 4 \pm 5 \cdot 6$ & $111 \cdot 1+4 \cdot 2$ \\
60 & $121 \cdot 3 \pm 7 \cdot 7$ & $141 \cdot 3 \pm 7 \cdot 3$ & $130 \cdot 1 \pm 6 \cdot 1$ & $151 \cdot 6+7 \cdot 4$ \\
90 & $94 \cdot 8 \pm 4 \cdot 5$ & $134 \cdot 8 \pm 7 \cdot 1$ & $102 \cdot 3 \pm 4 \cdot 8$ & $156 \cdot 5+5 \cdot 8$ \\
120 & $77 \cdot 8 \pm 3 \cdot 1$ & $111 \cdot 2 \pm 6 \cdot 6$ & $86 \cdot 0 \pm 4 \cdot 3$ & $135 \cdot 0+5 \cdot 7$ \\
150 & $71 \cdot 1 \pm 3 \cdot 2$ & $93 \cdot 5 \pm 5 \cdot 3$ & $76 \cdot 8 \pm 4 \cdot 3$ & $111 \cdot 5 \pm 6 \cdot 7$ \\
\hline
\end{tabular}

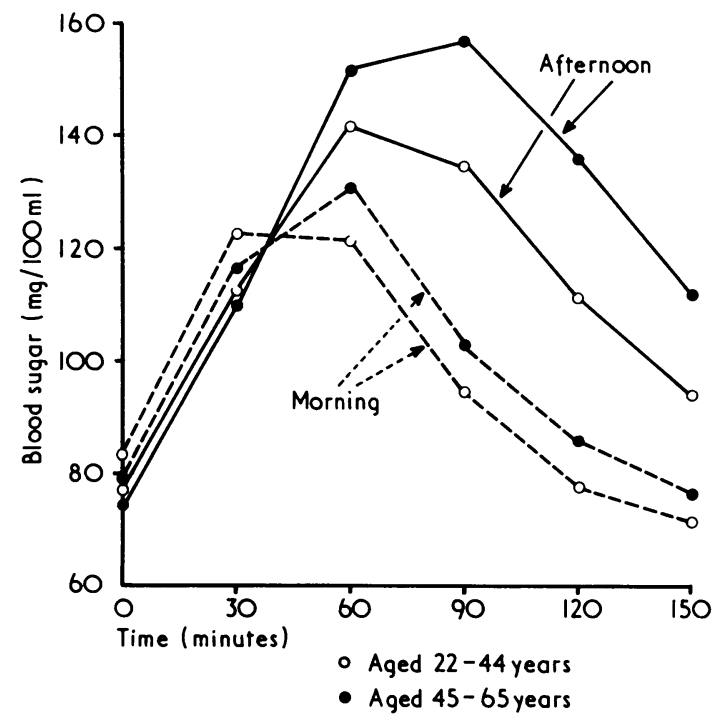

FIG. 2-Mean blood sugar levels in 22-44 and 45-65 age groups.

dimensions of the diurnal swing were greater in the older subjects.
Effect of Sex.-There was no significant difference in the mean age of the subjects grouped by sex (men $=43.9 \pm 3.6$ (S.E.M.); women $=45 \cdot 6 \pm 3 \cdot 2$ years). The mean blood sugar levels at 120 and 150 minutes were higher in the women both in the morning and afternoon (table IV). When this is taken into account there was no significant difference in the degree of diurnal variation between the sexes.

TABLE IV-Mean ( \pm S.E.M.) Blood Sugar Levels Morning and Afternoon by Sex

\begin{tabular}{|c|c|c|c|c|}
\hline \multirow{2}{*}{$\underset{\text { (minutes) }}{\text { Time }}$} & \multicolumn{2}{|c|}{$\operatorname{Men}(n=15)$} & \multicolumn{2}{|c|}{ Women $(n=16)$} \\
\hline & Morning & Afternoon & Morning & Afternoon \\
\hline $\begin{array}{r}0 \\
30 \\
60 \\
90 \\
120 \\
150\end{array}$ & $\begin{array}{r}80 \cdot 0 \pm 2 \cdot 5 \\
120 \cdot 6 \pm 4 \cdot 8 \\
129 \cdot 1+8 \cdot 1 \\
94 \cdot 3+3 \cdot 9 \\
76 \cdot 6 \pm 3 \cdot 4 \\
67 \cdot 4 \pm 2 \cdot 0\end{array}$ & $\begin{array}{r}77.5+2.2 \\
111.5 \pm 4.9 \\
146.6+7.9 \\
142.1 \pm 7.6 \\
111.9 \pm 6.5 \\
92.6 \pm 6.1\end{array}$ & $\begin{array}{r}80 \cdot 6 \pm 2 \cdot 5 \\
118 \cdot 3 \pm 5 \cdot 2 \\
122 \cdot 9 \pm 5 \cdot 8 \\
102 \cdot 8 \pm 5 \cdot 2 \\
87 \cdot 1 \pm 4 \cdot 0 \\
80 \cdot 3 \pm 4.5\end{array}$ & $\begin{array}{r}74 \cdot 6+1 \cdot 7 \\
112 \cdot 1+4 \cdot 5 \\
146 \cdot 6+7 \cdot 1 \\
149 \cdot 7+6 \cdot 4 \\
134 \cdot 4+5.9 \\
112.3+5 \cdot 8\end{array}$ \\
\hline
\end{tabular}

Effect of Obesity.-The interrelation of the degree of obesity, expressed as the body mass index, with the degree of diurnal variation in glucose tolerance is shown in table V. The body mass index (Keys et al., 1972) (weight in grammes divided by the square of the height in centimetres) was directly correlated with the degree of fatness-that is, the highest indices occurred in the most obese. The subjects were divided into two groups, those with an index of less than $25(n=16)$ and those with an index of 25 and above $(n=15)$. In the morning test the blood sugar levels at 60,90 , and 120 minutes were significantly higher in the "fatter" group. There was no significant difference in the afternoon test results between the two groups. Nevertheless, in the over 25 index group there was no significant difference between the blood sugar levels at 60 minutes in the morning and afternoon; thus the diurnal swing in this group was manifest only from 90 minutes after the glucose load.

TABLE V-Mean ( \pm S.E.M.) Blood Sugar Levels Morning and Afternoon by Body Mass Index

\begin{tabular}{|c|c|c|c|c|}
\hline \multirow{3}{*}{$\begin{array}{c}\text { Time } \\
\text { (minutes) }\end{array}$} & \multicolumn{4}{|c|}{ Body Mass Index } \\
\hline & \multicolumn{2}{|c|}{$<25(n=16)$} & \multicolumn{2}{|c|}{$25+(n=15)$} \\
\hline & Mornin & Afternoon & Morning & Afternoon \\
\hline $\begin{array}{r}0 \\
30 \\
60 \\
90 \\
120 \\
150\end{array}$ & $\begin{array}{r}80.4 \pm 2.6 \\
121.4 \pm 6.0 \\
113.3 \pm 4.7 \\
92.5 \pm 4.1 \\
78.0 \pm 3.5 \\
72.9 \pm 3.3\end{array}$ & $\begin{array}{r}74.9 \pm 2 \cdot 1 \\
114 \cdot 7+4 \cdot 9 \\
148 \cdot 1 \pm 7 \cdot 8 \\
141.9 \pm 7 \cdot 7 \\
119.7 \pm 7 \cdot 7 \\
98.9 \pm 7.0\end{array}$ & $\begin{array}{r}80 \cdot 1 \pm 2.3 \\
119 \cdot 6 \pm 3.6 \\
139.3 \pm 7.4 \\
104.1 \pm 4.9 \\
87.3 \pm 4.0 \\
76.7 \pm 4.2\end{array}$ & $\begin{array}{r}77 \cdot 2 \pm 1.8 \\
107.8 \pm 4.5 \\
145.0 \pm 7 \cdot 0 \\
152.1 \pm 5.9 \\
127.5 \pm 5.5 \\
106.9 \pm 5.6\end{array}$ \\
\hline
\end{tabular}

\section{PLASMA INSULIN}

The mean plasma insulin levels in the whole group at 30 minutes were significantly lower in the afternoon than in the morning, whereas at 120 and 150 minutes they were significantly higher in the afternoon (table VI).

Effect of Age.-The only significant difference in mean plasma insulin levels between the under 45 and 45 and over age groups was the lower level in the morning at 30 minutes in the older age group (table VII). 
TABLE VI-Mean ( \pm S.E.M.) Plasma Insulin Levels $(\mu U / m l)$ Morning and Afternoon in Whole Group

\begin{tabular}{|c|c|c|c|c|c|c|c|c|c|c|c|}
\hline & & & & & & \multicolumn{6}{|c|}{ Time (minutes) } \\
\hline & & & & & & 0 & 30 & 60 & 90 & 120 & 150 \\
\hline $\begin{array}{l}\text { Morning } \\
\text { Afternoon }\end{array}$ & . & $\begin{array}{l}\cdots \\
\cdots\end{array}$ & $\begin{array}{l}\cdots \\
\cdots\end{array}$ & $\begin{array}{l}. \\
\cdots\end{array}$ & $\begin{array}{l}\cdots \\
\cdots\end{array}$ & $\begin{array}{l}12 \cdot 6 \pm 1 \cdot 5 \\
11.5 \pm 1 \cdot 1\end{array}$ & $\begin{array}{l}35 \cdot 5 \pm 3 \cdot 5 \\
27 \cdot 8 \pm 2 \cdot 1\end{array}$ & $\begin{array}{l}43 \cdot 6 \pm 4 \cdot 5 \\
37 \cdot 7 \pm 4 \cdot 1\end{array}$ & $\begin{array}{l}29 \cdot 2 \pm 2 \cdot 4 \\
34 \cdot 8 \pm 3 \cdot 4\end{array}$ & $\begin{array}{l}21 \cdot 0 \pm 2 \cdot 0 \\
28 \cdot 8 \pm 2 \cdot 3\end{array}$ & $\begin{array}{l}16 \cdot 0 \pm 1 \cdot 7 \\
23 \cdot 0 \pm 1.9\end{array}$ \\
\hline
\end{tabular}

TABle viI-Mean ( \pm S.E.M.) Plasma Insulin Levels Morning and Afternoon by Age Group

\begin{tabular}{|c|c|c|c|c|}
\hline \multirow{2}{*}{$\begin{array}{c}\text { Time } \\
\text { (minutes) }\end{array}$} & \multicolumn{2}{|c|}{$22-44$ Years $(n=15)$} & \multicolumn{2}{|c|}{ 45-65 Years $(n=16)$} \\
\hline & Morning & Afternoon & Morning & Afternoon \\
\hline $\begin{array}{r}0 \\
30 \\
60 \\
90 \\
120 \\
150\end{array}$ & $\begin{array}{l}12.2 \pm 2.7 \\
41.0 \pm 5.8 \\
42.3 \pm 4.5 \\
28.5 \pm 3.6 \\
19.5 \pm 2.7 \\
15.9 \pm 2.6\end{array}$ & $\begin{array}{l}10 \cdot 5 \pm 1 \cdot 4 \\
29 \cdot 0 \pm 3 \cdot 2 \\
38 \cdot 2 \pm 4 \cdot 2 \\
34 \cdot 2 \pm 3 \cdot 1 \\
26 \cdot 9 \pm 3 \cdot 1 \\
21 \cdot 2 \pm 2 \cdot 6\end{array}$ & $\begin{array}{l}13.0 \pm 2.0 \\
30.3 \pm 3.7 \\
44.8 \pm 7 \cdot 7 \\
29.9 \pm 3.5 \\
22.5 \pm 3.1 \\
16.1 \pm 2.3\end{array}$ & $\begin{array}{l}12.5 \pm 1.7 \\
26.8 \pm 2.8 \\
37.2 \pm 7.0 \\
35.7 \pm 6.0 \\
30.6 \pm 3.3 \\
24.8 \pm 2.9\end{array}$ \\
\hline
\end{tabular}

Effect of Sex.-The mean levels of plasma insulin were significantly higher in men in the morning at 60 minutes. The levels at other time intervals were not significantly different (table VIII). Afternoon levels were significantly higher at 60 and 90 minutes in the men, but the pattern was similar in both sexes-a delayed rise, lower peak, and delayed fall.

Effect of Obesity.-The patterns of insulin response showed no real difference in relation to differences in body mass index (table IX). Perhaps surprisingly, there was no difference in mean morning or afternoon levels between the two groups.

TABLE viII-Mean ( \pm S.E.M.) Plasma Insulin Levels Morning and Afternoon by $\operatorname{Sex}$

\begin{tabular}{|c|c|c|c|c|}
\hline \multirow{2}{*}{$\begin{array}{c}\text { Time } \\
\text { (minutes) }\end{array}$} & \multicolumn{2}{|c|}{$\operatorname{Men}(n=15)$} & \multicolumn{2}{|c|}{ Women $(n=16)$} \\
\hline & Morning & Afternoon & Morning & Afternoon \\
\hline $\begin{array}{r}0 \\
30 \\
60 \\
90 \\
120 \\
150\end{array}$ & $\begin{array}{l}12 \cdot 2+2 \cdot 0 \\
38 \cdot 5 \pm 5 \cdot 0 \\
53 \cdot 0 \pm 7 \cdot 7 \\
32 \cdot 3 \pm 3 \cdot 5 \\
21 \cdot 3 \pm 2 \cdot 7 \\
14 \cdot 7 \pm 1 \cdot 8\end{array}$ & $\begin{array}{l}12.1 \pm 1.8 \\
32.5 \pm 2.8 \\
45.5 \pm 7.2 \\
40.9 \pm 6.4 \\
29.5 \pm 4.5 \\
21.0 \pm 3.3\end{array}$ & $\begin{array}{l}13 \cdot 0 \pm 2 \cdot 3 \\
32 \cdot 6 \pm 4 \cdot 8 \\
35 \cdot 0 \pm 3 \cdot 9 \\
26 \cdot 4 \pm 3 \cdot 3 \\
21 \cdot 0 \pm 3 \cdot 0 \\
17 \cdot 0 \pm 2 \cdot 8\end{array}$ & $\begin{array}{l}11 \cdot 0 \pm 1 \cdot 4 \\
22 \cdot 2 \pm 2.9 \\
30.4 \pm 3 \cdot 3 \\
29.1 \pm 2 \cdot 3 \\
26.6 \pm 2.0 \\
23.1 \pm 2.7\end{array}$ \\
\hline
\end{tabular}

TABLE IX-Mean ( \pm S.E.M.) Plasma Insulin Levels Morning and Afternoon by Body Mass Index

\begin{tabular}{|c|c|c|c|c|}
\hline \multirow{3}{*}{$\begin{array}{c}\text { Time } \\
\text { (minutes) }\end{array}$} & \multicolumn{4}{|c|}{ Body Mass Index } \\
\hline & \multicolumn{2}{|c|}{$<25(n=16)$} & \multicolumn{2}{|c|}{$25+(n=15)$} \\
\hline & Morning & Afternoon & Morning & Afternoon \\
\hline $\begin{array}{r}0 \\
30 \\
60 \\
90 \\
120 \\
150\end{array}$ & $\begin{array}{l}10 \cdot 6 \pm 1 \cdot 3 \\
38 \cdot 2 \pm 5 \cdot 1 \\
46 \cdot 4 \pm 6 \cdot 6 \\
29 \cdot 0 \pm 3 \cdot 0 \\
20 \cdot 5 \pm 2 \cdot 2 \\
15 \cdot 3 \pm 1 \cdot 7\end{array}$ & $\begin{array}{l}10 \cdot 2 \pm 1 \cdot 2 \\
30 \cdot 8 \pm 3 \cdot 2 \\
41 \cdot 4 \pm 7 \cdot 0 \\
37 \cdot 3 \pm 6 \cdot 0 \\
28 \cdot 2 \pm 2 \cdot 8 \\
21 \cdot 1 \pm 2 \cdot 0\end{array}$ & $\begin{array}{l}14 \cdot 8+2 \cdot 7 \\
32 \cdot 5 \pm 4 \cdot 8 \\
40 \cdot 6 \pm 6 \cdot 1 \\
29 \cdot 5 \pm 4 \cdot 0 \\
21 \cdot 6 \pm 3 \cdot 5 \\
16.7 \pm 3 \cdot 0\end{array}$ & $\begin{array}{l}12.9 \pm 1.9 \\
24.7 \pm 2.6 \\
33.7 \pm 3.8 \\
32.5 \pm 3.0 \\
29.4 \pm 3.7 \\
25.5 \pm 3.4\end{array}$ \\
\hline
\end{tabular}

\section{NON-ESTERIFIED FATTY ACIDS}

The mean fasting levels in the afternoon were significantly higher in the whole group and represented a $40 \%$ increase on the morning levels (table $\mathrm{X}$ ). The levels at all time intervals except at 150 minutes were also significantly higher in the afternoon. The effects of age, sex, and body mass index were studied but they did not significantly affect the results.

\section{PLASMA HUMAN GROWTH HORMONE}

There were no differences in the absolute levels or in the pattern of human growth hormone response apart from the level at $\mathbf{1 5 0}$ minutes in the afternoon (table XI).

\section{Discussion}

The results of the present study confirm that there is a diurnal variation in oral glucose tolerance. They also confirm the negative correlation between the degree of variation in morning and afternoon blood sugar responses and the degree of obesity, described first by Jarrett and Keen (1970) and later by Oakley et al. (1973). The degree of diurnal variation appears to be the same in men and women but is greater in older people.

The results of our plasma insulin measurements were qualitatively similar to those of Jarrett et al. (1972), Oakley et al. (1973), and Carroll and Nestel (1973). The major difference between morning and afternoon responses to the glucose load is in the pattern, with a tendency to a delayed and prolonged rise in plasma insulin in the afternoon. Nevertheless, as in our earlier study (Jarrett et al., 1972), the behaviour of plasma insulin within individuals was much less consistent than that of the blood sugar, suggesting that the impaired insulin response in the afternoon is not the sole cause of the impaired glucose tolerance. A change in insulin sensitivity must be invoked, and such a change in the hypoglycaemic potency of exogenous insulin, injected intravenously, has been shown by Gibson and Jarrett (1972). Our plasma growth hormone results do not support the hypothesis that growth hormone might be the cause of insulin resistance. The findings of Oakley et al. (1973) and Carroll and Nestel (1973) are also inconsistent with this hypothesis. We did not measure another candidate for this rolecortisol-but the well-known diurnal variation of this hormone is in the wrong direction to explain impairment of glucose tolerance late in the day.

table X-Mean ( \pm S.E.M.) Plasma Non-esterified Fatty Acid Levels $\mu$ Eq/l.) Morning and Afternoon in Whole Group

\begin{tabular}{|c|c|c|c|c|c|c|c|c|c|c|c|}
\hline \multirow[b]{2}{*}{$\begin{array}{l}\text { Morning } \\
\text { Afternoon }\end{array}$} & \multirow{2}{*}{\multicolumn{2}{|c|}{$\begin{array}{l}. \\
\cdots\end{array}$}} & \multirow[b]{2}{*}{. } & \multirow[b]{2}{*}{$\therefore$} & \multirow[b]{2}{*}{$\begin{array}{l}\cdots \\
\cdots\end{array}$} & \multicolumn{6}{|c|}{ Time (minutes) } \\
\hline & & & & & & $\begin{array}{l}513 \cdot 7 \pm 35 \cdot 6 \\
718 \cdot 8 \pm 58 \cdot 2\end{array}$ & $\begin{array}{l}368 \cdot 2 \pm 24 \cdot 7 \\
502 \cdot 9 \pm 37 \cdot 5\end{array}$ & $\begin{array}{l}209 \cdot 9 \pm 18 \cdot 7 \\
276 \cdot 6 \pm 22 \cdot 4\end{array}$ & $\begin{array}{l}157.9 \pm 12 \cdot 3 \\
211.3 \pm 18.5\end{array}$ & $\begin{array}{l}143.3 \pm 12.4 \\
174.5 \pm 94.5\end{array}$ & $\begin{array}{l}182 \cdot 1 \pm 23.0 \\
178.6 \pm 16 \cdot 2\end{array}$ \\
\hline
\end{tabular}

TABLE XI-Mean ( \pm S.E.M.) Plasma Growth Hormone Levels $(\mu I U / m l)$ Morning and Afternoon in Whole Group

\begin{tabular}{|c|c|c|c|c|c|c|c|c|c|c|}
\hline & & & & & \multicolumn{6}{|c|}{ Time (minutes) } \\
\hline & & & & & 0 & 30 & 60 & 90 & 120 & 150 \\
\hline $\begin{array}{l}\text { Morning } \\
\text { Afternoon }\end{array}$ & $\begin{array}{ll}\ldots & \cdots \\
\ldots & \cdots\end{array}$ & $\begin{array}{l}\cdots \\
\cdots\end{array}$ & $\begin{array}{l}\cdots \\
\cdots\end{array}$ & $\begin{array}{l}\cdots \\
\cdots\end{array}$ & $\begin{array}{l}2.48+0.51 \\
3.33+0.82\end{array}$ & $\begin{array}{l}1.44 \pm 0.32 \\
2.08 \pm 0.46\end{array}$ & $\begin{array}{l}1.32 \pm 0.29 \\
1.56 \pm 0.36\end{array}$ & $\begin{array}{l}1.20 \pm 0.27 \\
1.52 \pm 0.42\end{array}$ & $\begin{array}{l}1.48 \pm 0.37 \\
1.54 \pm 0.33\end{array}$ & $\begin{array}{l}1.83 \pm 0.38 \\
3.58 \pm 0.76\end{array}$ \\
\hline
\end{tabular}


In this context the non-esterified fatty acid levels are of considerable interest. The afternoon fasting levels were almost always significantly higher than those in the morning, confirming the observations of Carroll and Nestel (1973), who compared values at 07.00 and 19.00 hours. Non-esterified fatty acids have been shown to be insulin antagonists in that their metabolism impairs glucose uptake by muscle (Randle et al., 1963; Seyffert and Madison, 1967). Baker and Mottram (1973), have reported a reduced uptake of glucose by human forearm muscles in the afternoon. Possibly increased lipolysis causing raised plasma non-esterified fatty acid levels and a consequent increase in their metabolism by muscle might be responsible for this phenomenon. Studies of forearm tissues during glucose tolerance tests have shown that glucose uptake is greater in lean than in obese subjects (Butterfield et al., 1967; Whichelow and Butterfield, 1971). Thus a change in peripheral glucose uptake due to a change in insulin sensitivity, whether or not induced by nonesterified fatty acids, might be expected to affect blood sugar levels more in the lean than in the obese, which conforms with the observations in the present study and with those of Jarrett and Keen (1970), Gibson and Jarrett (1972), and Oakley et al. (1973). The reason for the higher afternoon level of nonesterified fatty acid is unknown, but from the observations of Carroll and Nestel (1973) and Stimmler et al. (1973) it seems unlikely that exercise can be held solely responsible.

We are indebted to all those who volunteered as subjects for this investigation. Facilities were kindly made available in the medical department of the Greater London Council and we are grateful to Drs. A. B. Stewart, G. Wigley, and T. Hall, and to Mr. R. C. Coulter of the medical department for their help in making the study possible. Mr. K. Kilbourn and Mr. P. Rutland provided able technical help. P.Z.Z. wishes to thank the British Insulin Manufacturers for their financial support.

\section{References}

Baker, P. G. B., and Mottram, R. F. (1973). Clinical Science, 44, 479. Bowen, A. J., and Reeves, R. L. (1967). Archives of Internal Medicine, 119, 261 .

Butterfield, W. J. H., Abrams, M. E., St. John, D. J. B., and Whichelow, M. J. (1967). Metabolism, 16, 19 .

Carroll, K. F., and Nestel, P. J. (1973). Diabetes, 22, 333.

Carruthers, M., and Young, D. A. B. (1973). In Automation in Analytical Chemistry, ed. L. T. Skeegs. In press.

Gibson, T., and Jarrett, R. J. (1972). Lancet, 2, 947.

Jarrett, R. J., and Keen, H. (1969). British Medical fournal, 2, 341.

Jarrett, R. J., and Keen, H. (1970). British Medical fournal, 4, 334.

Jarrett, R. J., Baker, I. A., Keen, H., and Oakley, N. W. (1972). British Medical fournal, 1, 199.

Keys, A., Fidanza, F., Karvonen, M. J., Kimura, N., and Taylor, H. L. (1972). Fournal of Chronic Diseases, 25, 329.

Oakley, N. W., Monier, D., and Wynn, V. (1973). Diabetologia, 9, 235.

Randle, P. J., Garland, P. B., Hales, C. N., and Newsholme, E. A. (1963). Lancet, 1, 785.

Roberts, H. J. (1964). Fournal of the American Geriatrics Society, 12, 423.

Seyffert, W. A., Jr., and Madison, L. L. (1967). Diabetes, 16, 765.

Stimmler, L., Gibson, T., Shiu, M., Jarrett, R. J., and Rutland, P. (1973) Paper presented to the Autumn Meeting of the Medical and Scientific Section of the British Diabetic Association.

Whichelow, M. J., and Butterfield, W. J. H. (1971). Quarterly fournal of Medicine, 40, 261.

\section{Diurnal Variation in Response to Intravenous Glucose*}

\author{
MARGARET J. WHICHELOW, \\ SUSAN GRAINGER \\ R. A. STURGE, \\ H. KEEN, \\ R. J. JARRETT, \\ L. STIMMLER,
}

British Medical fournal, 1974, 1, 488-491

\section{Summary}

Intravenous glucose tolerance tests $(25 \mathrm{~g})$ were performed in the morning and afternoon on 13 apparently normal persons. The individual $\mathbf{K}$ values (rate of decline of blood sugar) were all higher in the morning tests, and the mean values were significantly higher in the morning. Fasting blood sugar levels were slightly lower in the afternoon. There was no difference between the fasting morning and afternoon plasma insulin levels, but the levels after glucose were lower in the afternoon. Growth hormone levels were low at all times in nonapprehensive subjects and unaffected by glucose. The results suggest that the impaired afternoon intravenous glucose tolerance, like oral glucose tolerance, is associated with impaired insulin release and insulin resistance.

*Paper presented at the 8th Congress of the International Diabetes Federation, Brussels, July 1973.

\section{Introduction}

Various groups of workers (Roberts, 1964; Bowen and Reeves, 1967; Jarrett and Keen, 1969) have established that in nondiabetic subjects the curve of glycaemia after oral glucose is higher in the afternoon than in the morning and that the relative glucose intolerance in the afternoon is associated with a delayed and lower insulin response (Jarrett et al., 1972; Carroll and Nestel, 1973; Oakley et al., 1973). Gibson and Jarrett (1972), however, have also shown that after the intravenous injection of insulin blood sugar depression is also less in the afternoon. Thus two factors-diminished insulin release and increased resistance to the peripheral effects of insulin-may be responsible for the afternoon intolerance.

Insulin release after oral gluoose is influenced by intestinal factors such as differing absorption rates and the release of gut hormones, and these might, in part, be responsible for diurnal differences in glucose tolerance. To investigate the possible role of intestinal factors we have compared the response to intravenous glucose in the morning and afternoon in nondiabetic subjects.

\section{Subjects and Methods}

Details of the 13 subjects ( 7 men and 6 women) who successfully completed both the morning and afternoon tests are given in table I. The group was composed mostly of hospital staff but also included patients convalescing from various onthopaedic disorders. None of the subjects was obese and none had any prior clinical or biochemical evidence of diabetes mellitus or other metabolic disturbance. 